\title{
Quality of cause-of-death statements and its impact on infant mortality statistics in Hermosillo, Mexico
}

\author{
Gerardo Álvarez, ${ }^{1}$ Siobán D. Harlow, ${ }^{2}$ Catalina Denman, ${ }^{3}$ \\ and Mary J. Hofmeister ${ }^{2}$
}

Suggested citation Álvarez G, Harlow SD, Denman C, Hofmeister MJ. Quality of cause-of-death statements and its impact on infant mortality statistics in Hermosillo, Mexico. Rev Panam Salud Publica. 2009;25(2):120-7.

ABSTRACT Objectives. This study evaluates the quality (completeness and accuracy) of cause-of-death (COD) statements in infant death certificates as entered into a vital records system and assesses its impact on infant mortality statistics in Hermosillo, Sonora, Mexico.

Methods. COD statements in a systematic random sample of 200 infant death certificates were compared to their corresponding medical charts. The underlying CODs (UCODs) originally recorded in each death certificate were contrasted with those assigned by an expert reviewer. Coding for the original and "new" UCODs was based on the three-digit category of the International Classification of Diseases, 10th Revision. Measurements of agreement between the two sets of UCODs were calculated and logistic regression was performed to determine factors associated with agreement.

Results. Overall agreement between the original and new UCODs was 52\%. Agreement was excellent for the group of deaths due to congenital malformations, deformations, and chromosomal abnormalities (kappa $=0.77$ ); substantial for conditions originating in the perinatal period (kappa $=0.74)$; and poor for certain infectious and parasitic diseases, and respiratory diseases (kappa $=0.35$ ). Overestimation (false-positive reporting) was highest $(13 \%)$ for perinatal conditions, while underestimation (false-negative reporting) was highest (71\%) for certain infectious and parasitic diseases, and respiratory diseases. Agreement was associated with type of UCOD (endogenous versus exogenous) and time of death.

Conclusion. More than half (53\%) of COD statements in infant death certificates in Hermosillo were inaccurately completed, which may lead to inaccurate interpretation of causes of infant mortality. Systematic assessments of the quality of COD statements may improve the quality of mortality statistics.

Key words Cause of death, infant mortality, data analysis, mortality registries, Mexico.

Biological Sciences and Health Division, Faculty of Medicine, Universidad de Sonora (UNISON), Hermosillo, Sonora, Mexico. Send correspondence and reprint requests to: Gerardo Álvarez, Assistant Professor, UNISON-Medicine, Blvd. Luís Donaldo Colosio y Reforma, Edificio 7-C, Planta Alta, Colonia Centro, Hermosillo, Sonora 83260, Mexico; telephone: (662) 259-2121; e-mail: galvarez@ guayacan.uson.mx

2 School of Public Health, University of Michigan, Ann Arbor, Michigan, United States of America.

3 Health and Gender Program, El Colegio de Sonora, Hermosillo, Sonora, Mexico.
In most countries, death certificates constitute the largest disease-related source of information at the national, state, and local levels and thus have a significant effect on public health research and policy-making (1-3). Many middle-income countries, including Mexico, have established vital registration systems to compile their mortality statistics. However, the utility and quality of the data generated from these systems has seldom been evaluated. Studies on the quality of death registration systems usually compare information on death certificates with data from other sources, such as autopsies, medical charts, or evaluation by expert reviewer panels, to determine the completeness 
and accuracy of the death-certificate data (4-8). To date, few such studies have been undertaken in Mexico (9-11).

In Sonora, a state in northwestern Mexico, cause-of-death (COD) statements reported in a standard format following World Health Organization (WHO) guidelines (12) are systematically entered into a digital database known as the Epidemiologic and Statistical Mortality System (SEED) (13). This article reviews the completeness and accuracy of COD statements recorded in a systematic random sample of infant death certificates and assesses the impact of inaccurate COD statements on mortality statistics in Hermosillo, the capital city of Sonora, Mexico.

\section{MATERIALS AND METHODS}

A medical record review was carried out in 2005 to investigate the completeness and accuracy of COD statements in death certificates from the period 20022003 entered into the SEED database of the city of Hermosillo in Sonora, Mexico. Hermosillo comprises an urban area, with an estimated population of 666959 for the year 2003, plus a surrounding sparsely populated rural area. During the period 2002-2003, 23858 births and 365 deaths of infants aged less than 1 year were registered in Hermosillo hospital facilities. Of the 365 corresponding death certificates, 314 met the study inclusion criteria (i.e., they listed a permanent address within the urban area of Hermosillo and their COD statements had been entered into the SEED database during 2002-2003). Of these 314 eligible death certificates, 200 were selected for study through systematic random sampling. All 200 death certificates included in the study sample were recorded at three public hospitals in the urban area of Hermosillo.

The 200 selected death certificates were reviewed for completeness and accuracy. On an accurately completed death certificate, both the UCODs (the conditions that triggered the diseases, injuries, or complications leading to death) and the ICODs (the immediate or final complication resulting from the UCODs) are recorded in Part I (the "COD" portion) of the medical section of the death certificate $(14,15)$, while "other significant conditions" (those contributing to death but not resulting in its underlying causes) are recorded in Parts II and III
(16). For this study, a death certificate was considered to be inaccurately completed when any of the following occurred: (a) CODs were ill-defined or recorded as "unknown" in Part I; (b) an erroneous COD sequence was recorded in Part I (i.e., anything other than ICODs recorded on line " $a$ " and UCODs recorded on lines " $b$," "c," and "d"); (c) a UCOD or ICOD was recorded in Part II; (d) abbreviations were used in Part I; (e) "other significant conditions" related to the death were recorded in Part I; (f) incidental findings (i.e., miscellaneous notes about the death) were recorded in Parts I or II; and/or (g) missing data in any part of the death certificate $(12,17)$.

The first step of the review included abstraction of the 200 original COD statements (those extracted from the systematic random sample of 200 death certificates). The codes for the original UCODs were based on the three-digit category of the International Classification of Diseases, 10th Revision (ICD-10). Next, two physicians, blinded to the original COD statements, abstracted relevant COD information for each decedent from the corresponding medical chart of the hospital where the death occurred. Abstraction was done using a standardized form, and the physicians were trained in the $\mathrm{WHO}$ selection rules (guidelines) for completing Part I (the "COD" portion) of the medical section of the death certificate. Subsequently, expert reviewers examined the physicianassigned COD statements and the original COD statements and determined the correct UCODs (henceforth known as the "new" UCODs), resolving any discrepancies between the two sets of COD statements by checking the corresponding medical charts. The new UCODs were then coded by the Sonora Health Department based on the three-digit category of the ICD-10.

Both the original and new UCODs were classified into two categories: endogenous causes (including neoplasms; blood diseases; endocrine, nutritional, and metabolic diseases; certain conditions originating in the perinatal period; and congenital malformations, deformations, and chromosomal abnormalities), and exogenous causes (including respiratory infections, infectious and parasitic diseases, and accidents and other external CODs) (18).

The original UCODs (those from the 2002-2003 death certificates) were then compared to the new UCODs (those determined by the expert reviewers) to measure concordance between the two sets of data, with the new UCODs used as the "gold standard" for all subsequent analyses. To measure concordance between the original and new UCODs, the rate of overall agreement, percent positive agreement (number of occurrences for which both data sets report a positive result), false-positive reporting, and false-negative reporting, and the kappa coefficient (the rate of agreement adjusted for agreement that may have occurred by chance) were estimated (19-22). Kappa values greater than 0.75 were considered excellent agreement beyond chance, whereas values from 0.61 to 0.74 were considered substantial agreement; those from 0.41 to 0.60 were considered moderate agreement; and those below 0.40 were considered poor agreement (20, 22). False-positive and false-negative rates higher than $10 \%$ and $40 \%$, respectively, were considered unacceptably high based on previous reports $(1,19,23)$. Agreement between the original and new UCODs was determined based on the ICD-10 definitions.

To evaluate the effect of inaccurately completed COD statements on infant mortality statistics, age-adjusted mortality rates were estimated using the new UCODs and compared with the original estimated age-adjusted rates (those based on the original UCODs). To illustrate the net effect of false-positive and falsenegative reporting of UCODs on infant mortality statistics, mortality rate ratios (MRRs) (the ratios of rates determined according to the original UCODs versus those determined according to the new UCODs) were estimated for infants aged less than 28 days (perinatal period) and infants aged more than 28 days (postneonatal period) (19).

Descriptive statistics were used to analyze additional information gathered from the death certificates, including type of personnel who certified the death (attending physician versus "other" physician); medical insurance enrollment ("yes" versus "no"); type of hospital (facility for uninsured versus facility for insured); type of UCOD (exogenous versus endogenous); and time of death (morning, evening, or night, based on standard time frames of 7 am to $2: 30 \mathrm{pm}$, 2:31 pm to 9:30 pm, and 9:31 pm to 6:59 am, respectively, adjusted according to any differences in specific hospital 
shifts). The association between these variables and the probability of agreement between the original and new UCODs was then analyzed using logistic regression. Backward stepwise regression was used to determine the statistically significant factors to be included in the final model. All statistical procedures were performed using the statistical software SAS (version 8.2, SAS Institute, Inc., Cary, North Carolina, USA). For all statistics, an alpha level of 0.05 and $95 \%$ CIs were used.

\section{RESULTS}

Of the 200 infant deaths reviewed, $82 \%$ occurred in the perinatal period, and $92 \%$ were attributable to endogenous causes. Most of the deaths $(76 \%)$ were certified by a physician other than the attending physician, $52 \%$ of the deceased did not have any medical insur- ance, and $58 \%$ of the deaths occurred in Pediatric Hospital at Sonora State, a public hospital for the uninsured.

Based on the study criteria, 53\% $(n=106)$ of the death certificates were inaccurately completed: $40 \%$ had an erroneous COD sequence (i.e., reversal of "underlying" versus "immediate" causes) in Part I of the medical section; $8 \%$ had UCODs recorded in Part II (versus Part I) of the medical section; $3 \%$ had missing information; and 2\% had abbreviations in Part I. The overall rate of agreement between the original and newly assigned UCODs was 52\% $(n=104)$. The rate of agreement across categories of selected variables is illustrated in Table 1. Time of death (evening or night versus morning hospital employment shift) and type of UCOD (endogenous versus exogenous) both increased the likelihood of agreement. There was no significant difference in the distribution of the rate of agreement by sex of the deceased, type of personnel certifying the death (attending physician versus "other" physician), medical insurance enrollment ("no" versus "yes"), type of hospital where the death took place (facility for uninsured versus facility for insured), completeness of death certificate ("yes" versus "no"), or age at time of death ("less than 28 days" versus "28-180 days" or "more than 180 days").

As shown in Table 2, the extent of agreement, as measured by the kappa coefficient, was excellent for the group of deaths due to congenital malformations, deformations, and chromosomal abnormalities (kappa $=0.77$ ); substantial for conditions originating in the perinatal period, and for neoplasms, blood diseases, and endocrine and metabolic diseases (kappa $=0.74$ and 0.53 , respectively); and poor for certain infectious and parasitic diseases, and respiratory

TABLE 1. Rate of agreement between original (2002-2003) and expert-reviewer (2005) cause-of-death (COD) statements for infant death certificates from Hermosillo, Sonora, Mexico, ${ }^{a}$ by selected characteristics

\begin{tabular}{|c|c|c|c|c|}
\hline Characteristic & Deaths & $\begin{array}{l}\text { Number of COD statements } \\
\text { in agreement (original } \\
\text { and expert-reviewer) } \\
\text { based on ICD-10 } 10^{\mathrm{b}} \text { definitions }\end{array}$ & $\%$ of agreement & $P$-value ${ }^{\mathrm{c}}$ \\
\hline Overall agreement & 200 & 104 & 52.0 & \\
\hline \multicolumn{5}{|l|}{ Sex of deceased } \\
\hline Male & 116 & 63 & 54.3 & \multirow[t]{2}{*}{0.44} \\
\hline Female & 84 & 41 & 48.8 & \\
\hline \multicolumn{5}{|l|}{ Death certifier } \\
\hline Attending physician & 49 & 24 & 49.0 & \multirow[t]{2}{*}{0.65} \\
\hline Other physician & 151 & 80 & 53.0 & \\
\hline \multicolumn{5}{|c|}{ Medical insurance enrollment } \\
\hline No & 104 & 57 & 54.8 & \multirow[t]{2}{*}{0.41} \\
\hline Yes & 96 & 47 & 49.0 & \\
\hline \multicolumn{5}{|c|}{ Hospital where death occurred } \\
\hline Facility for uninsured & 116 & 66 & 56.9 & \multirow[t]{2}{*}{0.10} \\
\hline Facility for insured & 84 & 38 & 45.2 & \\
\hline \multicolumn{5}{|l|}{ Type of cause of death } \\
\hline Endogenous ${ }^{d}$ & 183 & 100 & 54.6 & \multirow[t]{2}{*}{0.01} \\
\hline Exogenous ${ }^{e}$ & 17 & 4 & 23.5 & \\
\hline \multicolumn{5}{|c|}{ Completeness $^{\dagger}$ of death certificate } \\
\hline Yes & 94 & 52 & 55.3 & \multirow[t]{2}{*}{0.55} \\
\hline No & 106 & 51 & 48.1 & \\
\hline \multicolumn{5}{|l|}{ Age of deceased } \\
\hline$<28$ days & 163 & 88 & 54.0 & \multirow[t]{3}{*}{0.48} \\
\hline $28-180$ days & 27 & 12 & 44.4 & \\
\hline$>180$ days & 10 & 4 & 40.0 & \\
\hline \multicolumn{5}{|l|}{ Time of death } \\
\hline 7:00 am-2:30 pm & 63 & 25 & 39.7 & \multirow[t]{3}{*}{0.03} \\
\hline $2: 31 \mathrm{pm}-9: 30 \mathrm{pm}$ & 60 & 38 & 63.3 & \\
\hline $9: 31 \mathrm{pm}-6: 59 \mathrm{am}$ & 73 & 39 & 53.4 & \\
\hline \multicolumn{5}{|c|}{$\begin{array}{l}\text { all } 200 \text { death certificates included in the study sample were recorded at three public hospitals in the urban area of Hermosillo, Sonora, Mexico (2002-2003). } \\
\text { b International Classification of Diseases, 10th Revision (ICD-10) (World Health Organization 1993). } \\
\text { c Calculated using the chi-squared test for equal proportions across categories according to agreement }(p<0.05) \text {. } \\
\text { d Includes neoplasms, blood diseases, endocrine and metabolic diseases; certain conditions originating in the perinatal period; and congenital malformations, defor- } \\
\text { mations, and chromosomal abnormalities. } \\
\text { e Includes infectious and parasitic diseases, and respiratory diseases. } \\
\text { f For this study, "accurately completed" death certificates are defined as those in which Parts I, II, and III of the medical section are fully and appropriately filled out } \\
\text { according to the guidelines of the ICD-10. }\end{array}$} \\
\hline
\end{tabular}


TABLE 2. Rate of agreement between original (2002-2003) and expert-reviewer (2005) cause-of-death (COD) statements for infant death certificates from Hermosillo, Sonora, Mexico, ${ }^{a}$ by main COD categories $^{b}$

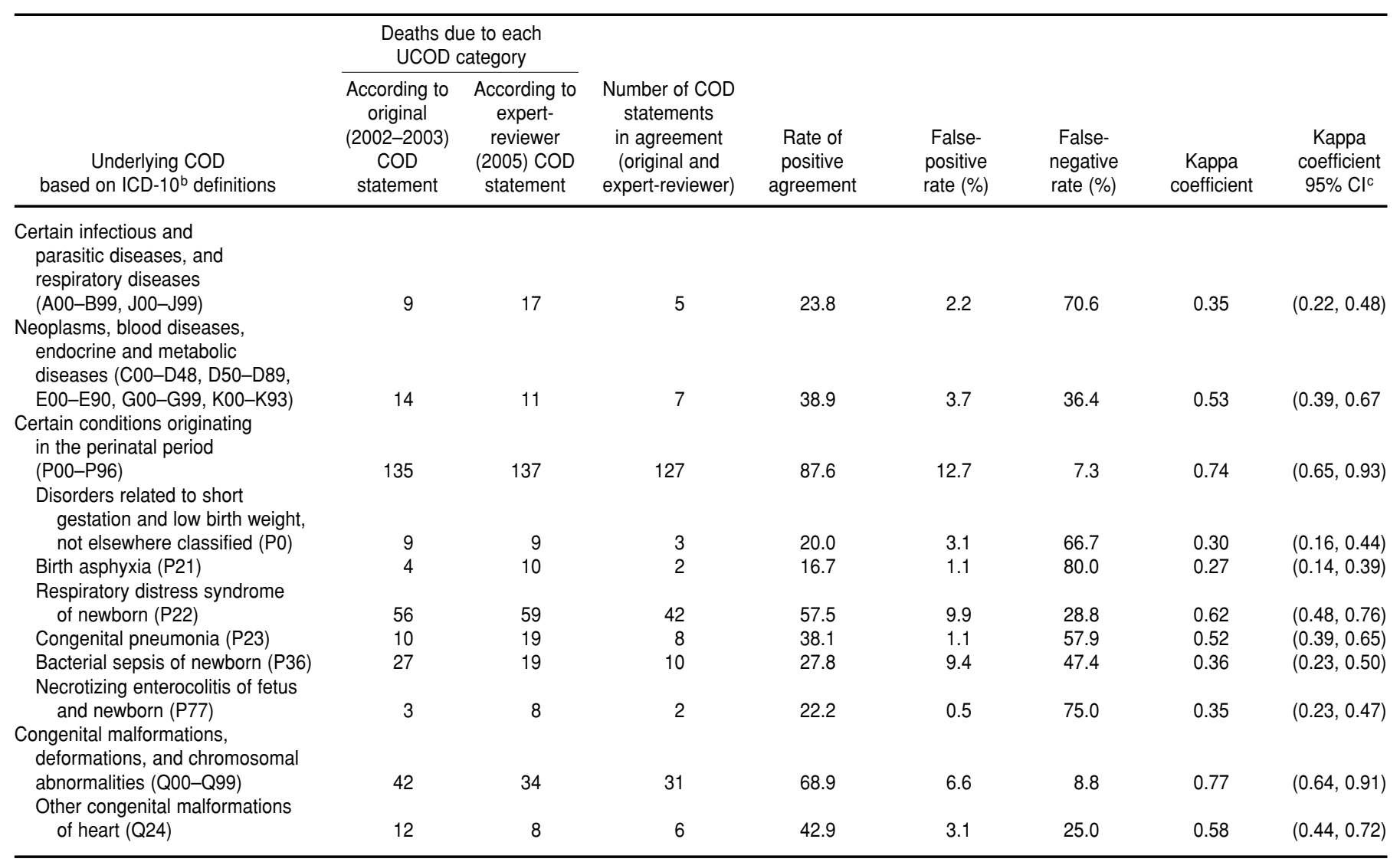

a All 200 death certificates included in the study sample were recorded at three public hospitals in the urban area of Hermosillo, Sonora, Mexico (2002-2003).

b International Classification of Diseases, 10th Revision (ICD-10) (World Health Organization 1993).

${ }^{c} \mathrm{Cl}=$ confidence interval.

diseases (kappa $=0.35)$. Overestimation (false-positive reporting) was highest $(13 \%)$ for perinatal conditions, whereas underestimation (false-negative reporting) was highest $(71 \%)$ for certain infectious and parasitic diseases, and respiratory diseases. When examining specific subgroups of CODs, the false-negative rate was high for birth asphyxia $(80 \%)$, necrotizing enterocolitis (75\%), disorders related to short gestation and low birth weight $(67 \%)$ and congenital pneumonia (58\%).

When analyzing agreement, both type of UCOD (endogenous versus exogenous) and time of death (morning [7 am to 2:30 pm] and evening [2:31 pm to 9:30 pm] versus night hospital employment shifts) decreased the likelihood of agreement between the original and new UCODs, as displayed in Table 3.

The age-adjusted mortality rates, based on the original UCODs (those assigned by the original death certifier) and the new UCODs, and the resulting
MRRs (the ratios of the original age-adjusted mortality rates to those based on the new UCODs) for the main groups of causes of perinatal and post-neonatal deaths are displayed in Table 4. For perinatal deaths, the MRR was significantly elevated (2.0) for the group of causes including neoplasms, blood diseases, and endocrine and metabolic diseases. When the MRR was estimated for specific categories of perinatal deaths, significant differences were observed for birth asphyxia (MRR $=0.4)$, congenital pneumonia $(M R R=0.5)$, and necrotizing enterocolitis (MRR $=0.4)$, as illustrated in Table 5 . No significant differences were found between the two sets of age-adjusted rates for deaths due to disorders related to short gestation and low birth weight; respiratory distress syndrome of newborn; bacterial sepsis of newborn; or congenital malformations, deformations, and chromosomal abnormalities. For post-neonatal deaths, the original UCODs underestimated the incidence of infec- tious and parasitic diseases, and respiratory diseases $(\mathrm{MRR}=0.6)$ and overestimated the incidence of certain conditions originating in the perinatal period $(\mathrm{MRR}=2.0)($ Table 4$)$

\section{DISCUSSION}

The SEED database, the most important source of data on mortality statistics for the Sonora Health Department, is based on COD statements from death certificates. To date, however, no assessments have been conducted to establish the quality of its data. This study identified problems in the completeness and accuracy of COD statements in infant death certificates from Hermosillo. Because these COD statements are entered into the SEED database, and Sonora infant mortality statistics are derived from the SEED data, the results of this study suggest systematic inaccuracies may be causing underestimation of infectious and parasitic diseases and overestima- 
TABLE 3. Variables for final multivariate regression modela used to assess agreement between original (2002-2003) and expertreviewer (2005) cause-of-death (COD) statements for infant death certificates from Hermosillo, Sonora, Mexicob

\begin{tabular}{|c|c|c|c|c|}
\hline Variable & Regression coefficient $(\beta)$ & $\mathrm{OR}^{\mathrm{c}}$ & $95 \% \mathrm{Cl}^{\mathrm{d}}$ & $P$-value ${ }^{e}$ \\
\hline Type of underlying $\operatorname{COD~(1~=~exogenous~cause~})$ & $N A^{\dagger}$ & 1.0 & NA & NA \\
\hline Type of underlying COD (endogenous cause) & 1.64 & 5.2 & $(1.4,9.1)$ & 0.01 \\
\hline Time of death $(1=$ night shift) & NA & 1.0 & NA & NA \\
\hline Time of death (morning shift) & 1.04 & 2.8 & $(1.3,6.3)$ & 0.01 \\
\hline Time of death (evening shift) & 0.77 & 2.2 & $(1.02,4.6)$ & 0.05 \\
\hline
\end{tabular}

a Backward stepwise regression was used to determine the statistically significant variables to be entered into the final model.

b All 200 death certificates included in the study sample were recorded at three public hospitals in the urban area of Hermosillo, Sonora, Mexico (2002-2003).

c Odds ratio adjusted by type of hospital where death occurred (facility for uninsured versus facility for insured); type of personnel certifying death (attending physician versus other physician); age at death (less than 28 days, 28-180 days, or more than 180 days); sex of deceased; enrollment in medical insurance ("yes" versus "no"); and completeness of death certificate ("yes" or "no," with "completeness" defined as Parts I, II, and III of the medical section fully and appropriately filled out according to the guidelines of the World Health Organization's International Classification of Diseases, 10th Revision [ICD-10]).

d $\mathrm{Cl}=$ confidence interval.

e Calculated using the chi-squared test for equal proportions across categories according to agreement $(p<0.05)$

f $\mathrm{NA}=$ not applicable.

TABLE 4. Comparison of estimated infant mortality rates based on original (2002-2003) and expert-reviewer (2005) cause-of-death (COD) statements for infant death certificates from Hermosillo, Sonora, Mexico, ${ }^{a}$ by main COD categories ${ }^{b}$

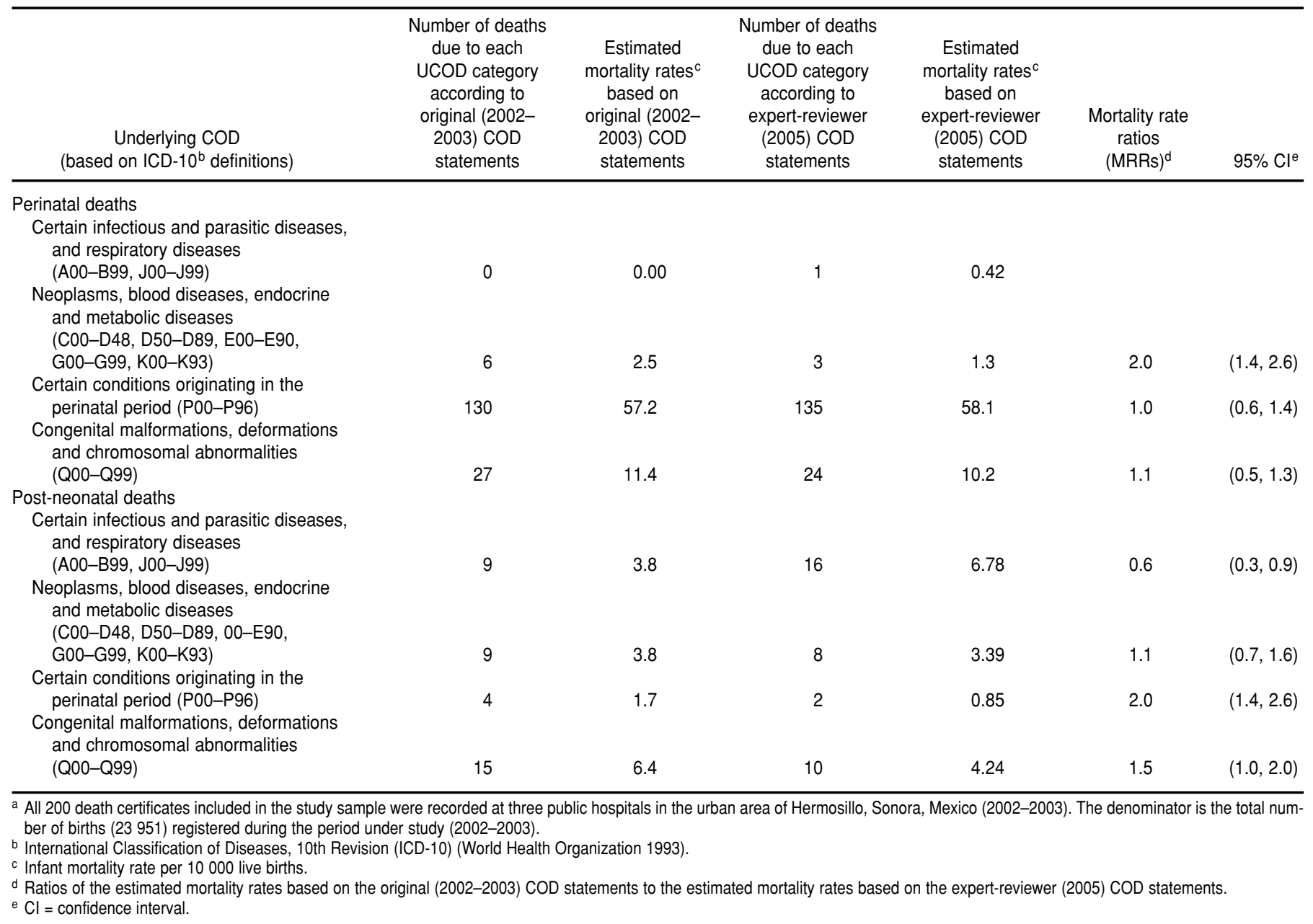

tion of conditions originating in the perinatal period, neoplasms, blood diseases, and endocrine and metabolic diseases as UCODs among infants.

In this study, it was observed that in the 200 death certificates selected through systematic random sampling, 53\% of death certificates were inaccurately completed, which may have a negative effect on the reliability of the state mortality statistics. A number of studies (15, 23-26) have reported that most problems with reliability of death certificates arise from failure to complete them properly. This failure is generally related to limited formal training of personnel in death-certification or disease-coding procedures $(5,15,27)$. Death certificates 
TABLE 5. Comparison of estimated perinatal mortality rates based on original (2002-2003) and expert-reviewer (2005) cause-of-death (COD) statements for infant death certificates from Hermosillo, Sonora, Mexico ${ }^{a}$

\begin{tabular}{|c|c|c|c|c|c|c|}
\hline $\begin{array}{c}\text { Underlying COD } \\
\text { (based on ICD-10 } 10^{\mathrm{b}} \text { definitions) }\end{array}$ & $\begin{array}{l}\text { Number of deaths } \\
\text { according } \\
\text { to original } \\
\text { (2002-2003) } \\
\text { COD statements }\end{array}$ & $\begin{array}{l}\text { Estimated mortality } \\
\text { rates }^{\mathrm{C}} \text { according } \\
\text { to original } \\
(2002-2003) \\
\text { COD statements }\end{array}$ & $\begin{array}{l}\text { Number of deaths } \\
\text { according to } \\
\text { expert-reviewer } \\
\text { (2005) COD } \\
\text { statements }\end{array}$ & $\begin{array}{l}\text { Estimated mortality } \\
\text { rates }^{c} \text { according to } \\
\text { expert-reviewer } \\
\text { (2005) COD } \\
\text { statements }\end{array}$ & $\begin{array}{l}\text { Mortality } \\
\text { rate ratios } \\
\text { (MRRs) }^{d}\end{array}$ & $95 \% \mathrm{Cl}^{\mathrm{e}}$ \\
\hline \multicolumn{7}{|l|}{$\begin{array}{l}\text { Certain infectious and parasitic diseases, } \\
\text { and respiratory diseases }\end{array}$} \\
\hline (A00-B99, J00-J99) & 0 & 0.00 & 1 & 0.42 & & \\
\hline \multicolumn{7}{|l|}{$\begin{array}{l}\text { Neoplasms, blood diseases, endocrine and } \\
\text { metabolic diseases (C00-D48, D50-D89, }\end{array}$} \\
\hline E00-E90, G00-G99, K00-K93) & 6 & 2.5 & 3 & 1.3 & 2.0 & $(1.4,2.6)$ \\
\hline \multicolumn{7}{|l|}{ Certain conditions originating in the } \\
\hline perinatal period (P00-P96) & 135 & 57.2 & 137 & 58.1 & 1.0 & $(0.6,1.4)$ \\
\hline \multicolumn{7}{|l|}{$\begin{array}{l}\text { Disorders related to short gestation } \\
\text { and low birth weight, not otherwise }\end{array}$} \\
\hline specified (P07) & 9 & 3.8 & 9 & 3.8 & 1.0 & $(0.6,1.4)$ \\
\hline Birth asphyxia (P21) & 4 & 1.7 & 10 & 4.2 & 0.4 & $(0.1,0.7)$ \\
\hline \multicolumn{7}{|l|}{ Respiratory distress syndrome } \\
\hline of newborn (P22) & 56 & 23.7 & 59 & 25.0 & 0.9 & $(0.6,1.3)$ \\
\hline Congenital pneumonia (P23) & 10 & 4.2 & 19 & 8.1 & 0.5 & $(0.2,0.8)$ \\
\hline Bacterial sepsis of newborn (P36) & 27 & 11.4 & 19 & 8.1 & 1.4 & $(0.9,1.9)$ \\
\hline \multicolumn{7}{|l|}{ Necrotizing enterocolitis of fetus } \\
\hline and newborn (P77) & 3 & 1.3 & 8 & 3.4 & 0.4 & $(0.1,0.7)$ \\
\hline \multicolumn{7}{|l|}{ Congenital malformations, deformations } \\
\hline and chromosomal abnormalities (Q00-Q99) & 27 & 11.4 & 24 & 10.2 & 1.1 & $(0.7,1.6)$ \\
\hline Other congenital malformations of heart (Q24) & 7 & 3.0 & 7 & 3.0 & 1.0 & $(0.6,1.4)$ \\
\hline
\end{tabular}

in Hermosillo public hospitals (where 95\% of 2002-2003 infant deaths occurred) are often filled out by medical students and residents with little experience or training in completing death certificates (5). This study's findings suggest a need for improvement in the training of death certifiers, particularly medical students. As shown by Myers (15), specific training offered to first-year postgraduate students can lead to dramatic improvements in the accuracy and correct completion of death certificate.

Analysis of the accuracy of the COD statements indicated discordance between almost $50 \%$ of the original UCODs and those assigned by the expert reviewer. This frequency of discordance is higher than that reported in other studies investigating accuracy of COD statements for children $(28,29)$. However, meaningful comparison between this study and previous studies is difficult due to the difference in the age groups studied (with the majority of previous studies limited to analysis of death certificates of adolescents). The process of death certification for infants is unique and merits further investigation to deter- mine the effect of various constraints specific to death certification for this age group that may affect the accuracy of the corresponding COD statements, including the tendency to misclassify (in the study setting) certain clinical conditions occurring among infants (e.g., respiratory distress syndrome and metabolic diseases); the frequent multiplicity of diseases or conditions related to the ultimate cause of infant deaths; and the very low rate of infant autopsies (30-32).

Agreement between the original and new UCOD codes was high for endogenous causes, which constitute $92 \%$ of all infant deaths in Hermosillo. However, there was substantial underestimation (false-negative reporting) of exogenous CODs, particularly of infectious diseases such as pneumonias and diarrheas, which may have significant implications for public health policy and programming. The study findings also suggest specific causes of perinatal mortality may be underestimated, including birth asphyxia, disorders related to short gestation and low birth weight, and necrotizing enterocolitis of fetus and newborn. Given that in Hermosillo, 3 out of 4 in- fant deaths occur during the perinatal period, it is essential for public health interventions to accurately determine the CODs in this category. This is a growing challenge, exacerbated by the fact that (1) most vital statistics systems in Mexico have failed to establish assurance/ quality control programs linking death certificate information with birth data, such as mother's obstetric history and last pregnancy, and (2) the current death certificate is not designed to capture clinical or epidemiological peculiarities occurring in the perinatal period, including short gestational age and low birth weight, as recommended in the ICD-10 $(11,33)$. Equally important is the need to assess problems in the process of assigning CODs of perinatal deaths, with particular focus on the use of codes P20, P21, and P07 (corresponding to intrauterine hypoxia, birth asphyxia, and disorders related to short gestation and low birth weight, respectively). Future studies in Hermosillo should focus on determining the actual incidence of perinatal conditions and investigate other potential factors associated with the risk of death, such as deficiencies in prenatal 
care and structural flaws in neonatal units.

Despite the fact that the false-positive and false-negative rates in this study were higher than reported in previous studies $(19,23)$, the net effect of disagreement between UCOD codes on reported mortality rates for endogenous and exogenous UCODs was not significant. A possible explanation for this is the compensatory effect of errors (17), in which diseases are over-coded in some individuals and under-coded in others due to erroneous or missing information on the death certificate. The second factor that could have obscured the net effect of UCOD discordance on mortality rates as detected in this study is the small sample size. Due to this limitation (the potential under-representation of the population in the study sample), no attempt is made to interpret the results beyond the study setting. However, the poor agreement rates and high false-negative and false-positive rates observed for some UCODs clearly suggest flaws in infant death certification in Hermosillo and therefore a high inaccuracy and low reliability in the corresponding infant mortality statistics.

Of all the variables analyzed for association with inaccurate UCODs, time of death proved to be a significant factor (i.e., it was significantly associated with a decreased likelihood of agreement between the original and newly assigned UCODs), specifically the morning and evening hospital employment shifts. This may be due to a high proportion of less experienced physicians and/or students filling out death certificates during those time periods. It should be noted that type of hospital (facility for uninsured versus facility for insured) and type of personnel certifying the death (attending physician versus "other" physician) have been associated with poor agreement of UCODs in other studies $(23,34)$.

Achieving accurate mortality statistics requires accuracy in both the completion of death certificate COD statements and the process of assigning UCODs. Therefore, efforts to improve mortality statistics in Hermosillo should include analysis of the reliability of the UCOD codification process. The SEED database currently has limited manpower and does not use an automated coding process, which may have a negative impact on the reliability of the resulting mortality statistics. To improve the accuracy of the information from this database, the SEED database could be linked to automated software such as the Automated Classification of Medical Entities (ACME) system developed by the U.S. National Center for Health Statistics, which standardizes the coding process, reduces the need for trained manpower (35), and serves as a helpful tool for monitoring and evaluating the quality of mortality statistics $(36,37)$.

In summary, this study found that inaccuracies in the completion of infant death certificates in Hermosillo are common (occurring in $53 \%$ of the study sample) and result in the registration of inaccurate UCODs, which in turn can affect the accuracy and reliability of local infant mortality statistics. These study re- sults suggest that strengthening educational interventions targeted at medical students and introducing automated tools in the UCOD coding process may improve the quality of the Sonora death certification system. Improving this system would, in turn, allow for more effective public health policy-making in Hermosillo by improving the accuracy of mortality statistics. The results of this study also underscore the usefulness of the SEED database utilized by the Sonora Health Department. This database could be used to facilitate (1) future evaluations of mortality data quality at state and local levels and (2) the examination of infant deaths in non-hospital settings (combined with the approach used in this study).

Acknowledgements. The authors thank the Fogarty International Center (FIC) and the Office of Behavioral and Social Science Research of the National Institutes of Health (Bethesda, Maryland, USA) for their support of this study, under the auspices of the FIC Maternal and Child Health Research Training Grant (TW01276). They also express their gratitude to the Hospital Infantil del Estado de Sonora (HIES) of Mexico's Ministry of Public Health, the Hospital de Ginecopediatría of the Mexican Institute of Social Security (IMSS), and the Hospital Ignacio Chávez of the Sonora Institute for Social Security and Services (ISSSTESON) for providing this study with the clinical information needed to perform the analysis for this report.

\section{REFERENCES}

1. D'Amico M, Agozzino E, Biagino A, Simonetti A, Marinelli P. Ill-defined and multiple causes on death certificates-a study of misclassification in mortality statistics. Eur J Epidemiol. 1999;15(2):141-8.

2. Rosenberg HM. Improving cause-of-death statistics. Am J Public Health. 1989;79(5): 563-4.

3. Kircher T, Anderson RE. Cause of death: proper completion of the death certificate. JAMA. 1987;258(3):349-52.

4. Mathers CD, Fat DM, Inoue M, Rao C, Lopez AD. Counting the dead and what they died from: an assessment of the global status of cause of death data. Bull World Health Organ. 2005;83(3):171-7.

5. Morton L, Omar R, Carroll S, Beirne M, Halliday D, Taylor KM. Incomplete and inaccurate death certification-the impact on research. J Public Health Med. 2000;22(2):133-7.
6. al-Mahroos R. Validity of death certificates for coding coronary heart disease as the cause of death in Bahrain. East Mediterr Health J [serial on the Internet]. 2000 [cited 2006 Dec 10];6(4):[about 3 p.]. Available from: http:// www.emro.who.int/Publications / EMHJ / 0604/06.htm.

7. Penson DF, Albertsen PC, Nelson PS, Barry $\mathrm{M}$, Stanford JL. Determining cause of death in prostate cancer: are death certificates valid? J Natl Cancer Inst. 2001;93(23):1822-3.

8. Cameron HM, McGoogan E. A prospective study of 1152 hospital autopsies: I. inaccuracies in death certification. J Pathol. 1981; 133(4):273-83.

9. Vandale S, Rascón-Pacheco R, Kageyama M. Time-trends and causes of infant, neonatal and postneonatal mortality in Mexico, 1980-1990. Salud Publica Mex. 1997;39(1): $48-52$.
10. Tomé $\mathrm{P}$, Reyes $\mathrm{H}$, Piña C, Rodríguez L, Gutiérez G. Características asociadas al subregistro de muerte en niños del estado de Guerrero, México. Salud Publica Mex. 1997;39(6): 523-9.

11. Contreras J, Flores S, Cardona J. Propuesta de un certificado de defunción para mejorar el registro y reporte de la muerte en el período perinatal. Salud Publica Mex. 2001;43(3):217-23.

12. World Health Organization. International classification of diseases and related health problems. 10th rev. Geneva: WHO; 1992.

13. Ministry of Health (MX), Directorate of Epidemiology. Manual de operaciones del Sistema Epidemiológico y Estadístico de Defunciones (SEED) [operations manual]. Mexico City: SSA/DGE; 1998.

14. Maudsley G, Williams EM. "Inaccuracy" in death certification-where are we now? J Public Health Med. 1996;18(1):59-66. 
15. Myers KA, Farquhar DR. Improving the accuracy of death certification. CMAJ. 1998;158(10): 1317-23.

16. Smith AE, Grover MH. Problems with proper completion and accuracy of the cause-of-death statement. Arch Intern Med. 2001;161(2):277-84.

17. Lu TH, Lee MC, Chou MC. Accuracy of cause-of-death coding in Taiwan: types of miscoding and effects on mortality statistics. Int J Epidemiol. 2000;29(2):336-43.

18. Matteson D, Burr J, Marshall J. Infant mortality: a multilevel analysis of individual and community risk factors. Soc Sci Med. 1998; 47(11):1841-53.

19. Nielsen GP, Björnsson J, Jonasson JG. The accuracy of death certificates: implications for health statistics. Virchows Arch A Pathol Anat Histopathol. 1991;419(2):143-6.

20. Landis JR, Koch GG. The measurement of observer agreement for categorical data. Biometrics. 1977;33(1):159-74.

21. Rosamond WD, Chambless LE, Sorlie PD, Bell EM, Weitzman S, Smith JC, et al. Trends in the sensitivity, positive predictive value, falsepositive rate, and comparability ratio of hospital discharge diagnoses codes for acute myocardial infarction in four US communities, 1987-2000. Am J Epidemiol. 2004;160(12): $1137-46$.

22. Szklo M, Nieto FJ. Quality assurance and control. In: Epidemiology: beyond the basics. Gaithersburg (MD): Aspen Publishers; 2000. p. 371-80.

23. Moussa MA, Shafie MZ, Khogali MM, elSayed AM, Sugathan TN, Cherian G, et al. Reliability of death certificate diagnoses. J Clin Epidemiol. 1990;43(12):1285-95.
24. Swift B, West K. Death certification: an audit of practice entering the 21st century. J Clin Pathol. 2002;55(4):275-9.

25. Lu TH, Shau WY, Shih TP, Lee MC, Chou MC, Lin CK. Factors associated with errors in death certification completion. A national study in Taiwan. J Clin Epidemiol. 2001;54(3): 232-8.

26. Huffman GB. Death certificates: why it matters how your patient died. Am Fam Physician. 1997;56(5):1287-8, 1290.

27. Nowels D. Completing and signing the death certificate. Am Fam Physician. 2004;70(9): $1813,1817-8$

28. Bang AT, Bang RA. Diagnosis of causes of childhood deaths in developing countries by verbal autopsy: suggested criteria. The SEARCH Team. Bull World Health Org. 1992; 70(4):499-507.

29. Evans PM, Alberman E. Certified cause of death in children and young adults with cerebral palsy. Arch Dis Child. 1991;66(3):325-9.

30. Schnitzer PG, Ewigman BG. Child injury deaths: comparing prevention information from two coding systems. J Pediatr Psychol. 2005;30(5):413-23.

31. Santoro A, Hackembruch C, Gutiérrez C, Repetto M, De Leonardis D, Rubio I, et al. Evolución de la mortalidad en el Hospital Pediátrico del Centro Hospitalario Pereira Rossell en el período 1999-2002. Informe del Comité de Auditoría de Fallecidos. Arch Pediatr Urug. 2003;74(3):212-8.

32. Feudtner C, Silveira MJ, Christakis DA. Where do children with complex chronic conditions die? Patterns in Washington State, 1980-1998. Pediatrics. 2002;109(4):656-60.
33. Laurenti R, Cravo MT, Di Nubila H, Buchalla $\mathrm{CM}$, Taniguchi $\mathrm{M}$. The codification of the cause of fetal and perinatal deaths [document on the Internet]. Geneva: World Health Organization; 2007 [cited 2008 Apr 14]. Available from: http://crs.sanita.fvg.it/WHO/ Documents/WHOFIC2007_D004.pdf.

34. Sibai A, Nuwayhid I, Beydoun M, Chaaya M. Inadequacies of death certification in Beirut: who is responsible? Bull World Health Organ. 2002;80(7):555-61.

35. National Center for Health Statistics (US). Vital statistics. ICD-10 ACME decision tables for classifying underlying causes of death. NCHS instruction manual; part 2c [manual on the Internet]. Hyattsville (MD): U.S. Department of Health and Human Services, Public Health Service; 2005 [cited 2006 Dec 10]. p. 13-1061. Available from: www.cdc.gov/nchs/ data/dvs/2c2005.pdf.

36. Israel RA. Automation of mortality data coding and processing in the United States of America. World Health Stat Q. 1990;43(4): 259-62.

37. Lu TH. Using ACME (Automated Classification of Medical Entry) software to monitor and improve the quality of cause of death statistics. J Epidemiol Community Health. 2003; 57(6):470-1.

Manuscript received on 22 November 2007. Revised version accepted for publication on 23 June 2008
RESUMEN

\section{Calidad de la consignación de la causa de muerte y su impacto en las estadísticas de mortalidad infantil en Hermosillo, México}

Palabras clave
Objetivos. Evaluar la calidad (grado de compleción y exactitud) de la consignación de la causa de muerte (CM) en los certificados de defunción de niños menores de 1 año, según los sistemas de registros demográficos, y determinar su impacto en las estadísticas de mortalidad de menores de 1 año en Hermosillo, Sonora, México.

Métodos. Se comparó la consignación de la CM en una muestra sistemática aleatoria de 200 certificados de defunción de niños menores de 1 año con sus correspondientes historias clínicas. Se contrastaron las CM subyacentes originales registradas en cada certificado de defunción con las CM subyacentes asignadas por un revisor experto. La codificación de las CM subyacentes, tanto las originales como las asignadas, se basó en las categorías de tres dígitos de la Clasificación Internacional de Enfermedades, $10{ }^{\text {a }}$ revisión. Se calcularon las medidas de concordancia entre los dos conjuntos de CM subyacentes y se determinaron los factores asociados con esa concordancia mediante regresión logística.

Resultados. La concordancia general entre las CM subyacentes originales y las asignadas fue de $52 \%$. La concordancia fue excelente en el grupo de muertes por malformaciones, deformaciones y alteraciones cromosómicas congénitas (kappa $=0,77$ ); fue notable en los trastornos originados en el período perinatal (kappa $=0,74)$; y baja en algunas enfermedades infecciosas, parasitarias y respiratorias (kappa $=0,35$ ). La sobreestimación (informes falsos positivos) fue mayor (13\%) en las afecciones perinatales, mientras que la subestimación (informes falsos negativos) fue mayor (71\%) en algunas enfermedades infecciosas, parasitarias y respiratorias. La concordancia se asoció con el tipo de CM subyacente (endógena vs. exógena) y el momento de la muerte.

Conclusiones. Más de la mitad $(53 \%)$ de las consignaciones de CM en los certificados de defunción de niños menores de 1 año en Hermosillo presentaban imprecisiones, lo que puede llevar a interpretaciones inexactas de las causas de la mortalidad en ese grupo de edad. La evaluación sistemática de la calidad de las declaraciones de CM puede ayudar a mejorar la calidad de las estadísticas de mortalidad.

Causas de muerte, mortalidad infantil, análisis de datos, registros de mortalidad, México. 